\title{
The identity of the largest enterprises located in Poland and communication of corporate social activities on corporate websites
}

Bartosz Seiler, Ph.D., University of Zielona Góra,

Faculty of Economics and Management, Poland, ORCID: 0000-0003-0380-746X.

Hanna Bortnowska, Ph.D. Eng., University of Zielona Góra,

Faculty of Economics and Management, Poland, ORCID: 0000-0002-7327-7524.

\section{Introduction}

The traditional division of organizations into commercial and those pursuing social utility goals is becoming outdated with the ever more popular hybridization, where organizations acquire the characteristics of entities representing various sectors of the economy (Cooney, 2006; Jäger and Schröer, 2014). On the one hand, nonprofit entities are employing paid staff while rationalizing and professionalizing their operations (Cumming, 2008; Hwang and Powell, 2009; Kreutzer and Jäger, 2011; Melnik et al. 2013; Carvalho et al. 2016; Sanzo-Perez et al. 2017), as well as economizing by initiating market activity (Weisbrod, 1998; Eikenberry and Kluver, 2004; Lloyd and Woodside, 2015). On the other hand, business enterprises activate in the area of the third sector by supporting non-governmental organizations in a substantive, material and financial way and by adopting elements of volunteering in their structures. Furthermore, they are implementing corporate social responsibility $(\mathrm{CSR})^{1}$ programs which go

1 A number of different definitions of CSR can be found in the literature. According to PN-ISO 26000: 2012 (p. 16), corporate social responsibility means the organization's responsibility for 
beyond compliance with the law, to embrace the image of a socially active, civic entity (Carroll, 1991; cf. Pope et al. 2018). Various forms of cross-sectoral cooperation are also being developed, including strategic alliances between nonprofit and for-profit organizations (Seitanidi and Crane, 2009; Sanzo-Perez et al. 2017). As a result, a broad spectrum of organizations can be observed that ranges from purely philanthropic to purely commercial (Dees, 1998).

Organizational identity, thus, emerges as a noteworthy topic in the context of progressive isomorphism and the overlapping of organizations representing different sectors and implementing corporate social activities (see: Knutsen, 2016). Organizational identity concerns issues related to what is enduring, central, distinctive in an organization (Albert and Whetten, 1985), as well as how it is perceived by employees and the environment. In Young (2001a; cf. 2001b), for example, we read there were three main identities of social enterprises in the United States at the turn of the twenty-first century: corporate philanthropist organizations, social purpose organizations, and hybrids. Meanwhile, Cunningham et al. (2009) studied how enterprises - through corporate social activities (sponsorship) - express their identity and shape their image in an environment. The foundation of an organizational identity (cf. Martinez et al. 2013), the form of its projection (see: Cunningham et al. 2009) are its mission, vision and values.

The aim of the article is: (a) to determine the prevalence of different types of missions and values in the largest enterprises located in Poland, especially those related to CSR; (b) to identify the relationship between the missions and CSR values declared by these enterprises and the presentation of selected corporate social activities on their corporate websites.

The article is divided into sections, which are: Introduction, Literature review, Methods, Results, and Conclusion.

\section{Organizational identity vs. corporate image}

In today's globalized yet individualized and fragmented world, the issue of identity is of particular importance. So much so, in fact, that identity is becoming a key category in social sciences. The term "identity" is used with reference to

the impact of its decisions and activities on society and the environment. It is ensured through transparent and ethical behavior which contributes to the sustainable development, health and welfare of the people, is not indifferent to the expectations of its stakeholders, acts in accordance with applicable laws and is consistent with international standards, all this while promoting the conduct worthy of the organization and relations practiced therein. 
individuals, groups, and organizations (Hatch, 2002, p. 254). In this last one, it assumes two main forms: corporate identity and organizational identity. The concept of corporate identity springs from the early days of graphic design and marketing research, and is a shorthand for presenting the specificity of an organization to a broader audience. Organizational identity, meanwhile, is a fruit of organizational behavior studies, aiming to get to the bottom of how employees perceive and jointly develop an understanding of the organization they create.

The terminological boom in this research area has a clear historical and interdisciplinary context. Scholars first got truly interested in exploring the identity of formalized secondary groups around the 1950s. Early researchers focused on how organizations are perceived by their employees and customers (Carter, 1982; Pilditch, 1970) - a construct known as corporate identity, which could be reduced to the question "Who do we want to be?" (Dowling and Otubanjo, 2011) and which draws from the tradition of designing and creating logotypes and interiors for corporations. The practical source of interest was the desire to convey what the organization was really about, as that would increase customers' and employees' trust and commitment to it. According to Olins (1978, 1995), corporate identity is a showcase of an organization's nature, or character, achieved with the help of communication tools, especially visual symbols such as name, logo and advertising slogans. Melewar and Karaosmanoglu (2006) argued, however, it is a showcase of an organization to every interested party, which includes all that makes the company unique, among others in terms of: organizational communication, design, culture, structure, staff behavior, strategy. Identity defined in this way is understood as a planned demonstration of the image of the organization. Gray and Balmer (1998) put it somewhat differently, by stating that corporate identity is the reality and uniqueness of an organization, which consists of its strategy, philosophy, culture and design.

When defining corporate identity, authors often list its constituent elements. And while they differ in the way they classify these, there is nonetheless agreement as to the symbols (company name, logotypes, typography, interior design of offices and means of transport, appearance of staff) forming the socalled visual identity of the company.

According to Hatch (2002, p. 256), the basic research issue here is to distinguish the concept of "identity" from another one that is closely related to it, namely "image". This distinction involves adopting a psycho-social or image/marketing approach to the organization. In the early works discussing this trend, these two terms were used interchangeably (as cited in: Simões et al. 2005), but this

The identity of the largest enterprises located in Poland and communication of corporate social activities on corporate 
would change over time. Image means a picture that appears in the minds of the audience when they hear the name of an organization or see its logo (Gray and Balmer, 1998). In other words, it is the impression the organization makes on others.

Only further down in the chronology did a theoretical construct referred to in the literature as "organizational identity" emerge. It originates from studies on organizational behavior and has a clear relationship with psychological and sociological understanding of identity. Scholars of this provenance began to consider issues of how staff develops a common understanding of the organization they create. In this case, the key question was "Who are we?". According to Albert and Whetten (1985), organizational identity is formulated around the central, permanent and distinctive elements of the organization. These are employees' beliefs about the organization as a whole and how they perceive themselves as its members (Hatch, 2002, p. 256).

For the needs of their membership identification model, Dutton et al. (1994) broke this concept down into perceived organizational identity and construed external image. Here, a parallel can be made to social psychology, to rename the latter to "looking-glass self" (Konecki, 2002, p. 82). Perceived identity relates to the characteristics of the organization considered by its members as central, distinctive and permanent. On the other hand, construed external image is a reconstruction by organization members of how the organization's main attributes are perceived externally, by the environment.

The literature points to the existence of a correlation between organizational identity and image (Whetten and Mackey, 2002; Hatch, 2002). The two concepts are related to each other, although they do not need to be coherent, as the organization may then be sending conflicting symbolic signals (Hatch, 2002). Gray and Balmer (1998) argue that organizational image management requires creation of a coherent identity communication system using various types of media, especially electronic. In the course of research carried out among managers dealing with corporate communication in the largest enterprises located in Poland, it was found that the importance of own modern corporate media, including websites, will grow in the coming years (Kończak, 2017), while the role of traditional media will be reduced to near obsolete.

Let us not forget that many authors are of the opinion that the mission, vision and values are the core of any organizational identity (cf. Martinez et al. 2013) or the form of its projection (see: Cunningham et al. 2009). For this reason, communication through modern media may encompass, among other things, the company's mission, ethical codes, and reports. 
As mentioned earlier, the identity of organizations pursuing social activities intrigues scholars regardless of whether the entity is profit-driven or not. As far as for-profits are concerned, identity issues are combined with those of business ethics and corporate social responsibility (CSR) (Martinez et al. 2013). In this context, organizational identity management involves elements such as forging coherent connections regarding the reference in the mission and values of the organization to the issues of environmental responsibility, backed by actual efforts, and then - their communication.

\section{Methods}

The conducted research comprised the following stages ${ }^{2}$ : formulation of questions, goals and hy potheses, determination of units of analysis, identification of texts, preparation of the coding scheme, testing it, purifying and/or detailing, collecting, coding and analysis of data. When formulating hypotheses (table 1), mission typology proposed by Cunningham et al (2009) and value taxonomy developed as part of the Corporate Values Index project (ECCO, 2013) were referred to.

\section{Table 1. Research hypotheses}

\begin{tabular}{|c|c|}
\hline \multicolumn{2}{|c|}{ Research hypotheses } \\
\hline $\begin{array}{l}\mathrm{H}_{1} \text { : Most of the analyzed organizations present } \\
\text { on their corporate websites missions that empha- } \\
\text { size social responsibility }\end{array}$ & $\begin{array}{l}\mathrm{H}_{2}: \text { Most of the analyzed organizations present } \\
\text { on their corporate websites values related to so- } \\
\text { cial responsibility.. }\end{array}$ \\
\hline $\begin{array}{l}\mathrm{H}_{3} \text { : Declaring "responsibility" in the company's } \\
\text { mission is irrelevant to presenting information } \\
\text { on CSR awards on corporate websites. }\end{array}$ & $\begin{array}{l}\mathrm{H}_{10} \text { : Declaring "attitude towards the environ- } \\
\text { ment" in the company's mission is irrelevant to } \\
\text { presenting information on CSR awards on cor- } \\
\text { porate websites. }\end{array}$ \\
\hline $\begin{array}{l}\mathrm{H}_{4} \text { : Declaring "responsibility" in the company's } \\
\text { mission is irrelevant to presenting information on } \\
\text { corporate social activities in the CSR reports }{ }^{3} \text {. }\end{array}$ & $\begin{array}{l}\mathrm{H}_{11} \text { : Declaring "attitude towards the environ- } \\
\text { ment" in the company's mission is irrelevant to } \\
\text { presenting information on corporate social ac- } \\
\text { tivities in the CSR reports. }\end{array}$ \\
\hline $\begin{array}{l}\mathrm{H}_{5} \text { : Declaring "responsibility" in the company's } \\
\text { mission is irrelevant to presenting information } \\
\text { on the implementation of corporate social ac- } \\
\text { tivities in a material and/or financial form on } \\
\text { corporate websites. }\end{array}$ & $\begin{array}{l}\mathrm{H}_{12} \text { : Declaring "attitude towards the environ- } \\
\text { ment" in the company's mission is irrelevant to } \\
\text { presenting information on the implementation } \\
\text { of corporate social activities in a material and/ } \\
\text { or financial form on corporate websites. }\end{array}$ \\
\hline
\end{tabular}

2 Inspired by the research scheme proposed by Insch et al. (1997).

3 The study included such messages mentioned both in CSR reports or elsewhere on the corporate website.

The identity of the largest enterprises

located in Poland and communication

of corporate social activities on corporate 
$\mathrm{H}_{6}$ : Declaring "responsibility" in the company's mission is irrelevant to presenting information on the implementation of corporate social activities in the form employee volunteering on corporate websites.

$\mathrm{H}_{7}$ : Declaring „responsibility” in the company's mission is irrelevant to presenting information on the implementation of corporate social activities for the benefit of NGOs on corporate websites.

$\mathrm{H}_{8}$ : Declaring "responsibility" in the company's mission is irrelevant to presenting information on the implementation of corporate social activities for the benefit of public organizations on corporate websites.

$\mathrm{H}_{9}$ : Declaring "responsibility" in the company's mission is irrelevant to presenting information on the implementation of corporate social activities for the benefit of individuals on corporate websites.
$\mathrm{H}_{13}$ : Declaring "attitude towards the environment" in the company's mission is irrelevant to presenting information on the implementation of corporate social activities in the form of employee volunteering on corporate websites.

$\mathrm{H}_{14}$ : Declaring "attitude towards the environment" in the company's mission is irrelevant to presenting information on the implementation of corporate social activities for the benefit of NGOs on corporate websites.

$\mathrm{H}_{15}$ : Declaring "attitude towards the environment" in the company's mission is irrelevant to presenting information on the implementation of corporate social activities for the benefit of public organizations on corporate websites.

$\mathrm{H}_{16}$ : Declaring "attitude towards the environment "in the company's mission is irrelevant to presenting information on the implementation of corporate social activities for the benefit of individuals on corporate websites.

Source: own study based on literature analysis

The study included enterprises from the 200 Largest Polish Companies ranking, published by the weekly „Wprost”. The ranking was based on the revenues, profits, assets and equity of several hundred Polish companies with predominantly Polish capital (https://rankingi.wprost.pl/200-najwiekszychfirm/2018, retrieved 24.02.2019). A total of 198 out of the 200 entities listed in the ranking were analyzed ${ }^{4}$. They differed in terms of sector (table 2), size, and geographical location. Capital groups constituted more than half of the sample (64.6\%), while production companies (30.3\%) and those dealing in wholesale and/or retail trade $(29.29 \%)$ were the second and third most numerous, respectively.

4 The website of one of the enterprises did not load, while the other excluded company was transformed in 2018 by the owners (both in terms of the scope of activity and the name of the organization). 
Table 2. Analyzed enterprises by sector

\begin{tabular}{l|c|c}
\hline Sector & $\begin{array}{c}\text { Number of ana- } \\
\text { lyzed enterprises } \\
{[\mathbf{N}]}\end{array}$ & $\begin{array}{c}\text { Share of analy- } \\
\text { zed enterprises } \\
{[\%]}\end{array}$ \\
\hline Industry (mining, food, chemical, wood, metal, etc.) & 60 & 30,3 \\
\hline Wholesale and/ or retail trade & 58 & 29,3 \\
\hline Construction and building materials & 22 & 11,1 \\
\hline $\begin{array}{l}\text { Services (finance and banking, logistics, security, job } \\
\text { placement, etc.) }\end{array}$ & 17 & 9,7 \\
\hline Energy & 7 & 3,5 \\
\hline Transport & 6 & 3,5 \\
\hline IT & 4 & 3,0 \\
\hline Media & 3 & 2,0 \\
\hline Machinery, devices, tools & 3 & 1,5 \\
\hline Automotive & 11 & 1,5 \\
\hline Other & 198 & 5,6 \\
\hline Total & 700 \\
\hline
\end{tabular}

Source: own study based on: https://rankingi.wprost.pl/200-najwiekszych-firm/2018 (24.02.2019 - access date)

It was assumed that, since the companies from the „Wprost” list were financially successful, they probably have their own, easily accessible website containing information sought in this study. It was also assumed that such companies have sufficiently large marketing budgets to conduct corporate social activities and inform about them through their corporate websites.

In the second quarter of 2019, proper research was conducted, consisting in the analysis of the content of websites. If it was not possible to locate the sought information via a link, the "Search ..." tool was used instead. Not only the information contained on the site was taken into account, but also that from any additional documents included on the website - reports, strategies, ethical codes, etc. Whenever the relevant information could not be found, further investigation of the site was abandoned. 
In the first stage, the missions and values of the organization included in the above-mentioned "Wprost" list were identified. In the second stage, data on the financing of social activities (e.g. areas, forms of engagement, beneficiaries) and employee volunteering was extracted. Subsequently, examination was carried out of how enterprises presented information on corporate social activities on their corporate websites.

During the research, not only specific words and phrases contained in the missions were searched, but also their synonyms. The context in which they were used as well as the links between the most common terms were also taken into account (using to this end the IRAMUTEQ software ${ }^{5}$ ). The collected data was quantified, which allowed for its further statistical processing (cf. Babbie, 2008; Silverman, 2009). Thus, both qualitative and quantitative approaches were combined in the content analysis. Statistical analyses were conducted using Microsoft Excel and IBM SPSS Statistics, allowing to calculate value of interests, arithmetic means, coefficients of variation. The Mann-Whitney $\mathrm{U}$ test was performed to test the validity of the formulated 14 hypotheses (see Section 5).

\section{Results of the analysis of the content of the missions and values, as presented by the largest companies located in Poland on corporate websites}

Over two-thirds of the companies (67.17\%) posted corporate missions on their websites, and nearly half $(45.5 \%)$ presented organizational values. The remaining enterprises did not include statements referring to mission and values on their websites, or simply decided not to make them available online.

When coding the words contained in the missions, the categories proposed by Cunningham et al. (2009) were used as a point of reference. These are: company success, product superiority, focus on competitors, innovation, being the best, focus on customers, diversity, value, ethics, employee focus, being helpful, responsibility, and improving quality of life. The prevalence of each of these values in the analyzed missions is shown in figure 1.

5 IRAMUTEQ is used for „extracting data from text materials, their structuring by searching for key words, phrases, sentences, and coding them in the form of numerical variables, as well as their subsequent statistical processing to discover (and often also to visualize) the existing correlations between them" (Glińska-Neweś and Escher, 2018). 


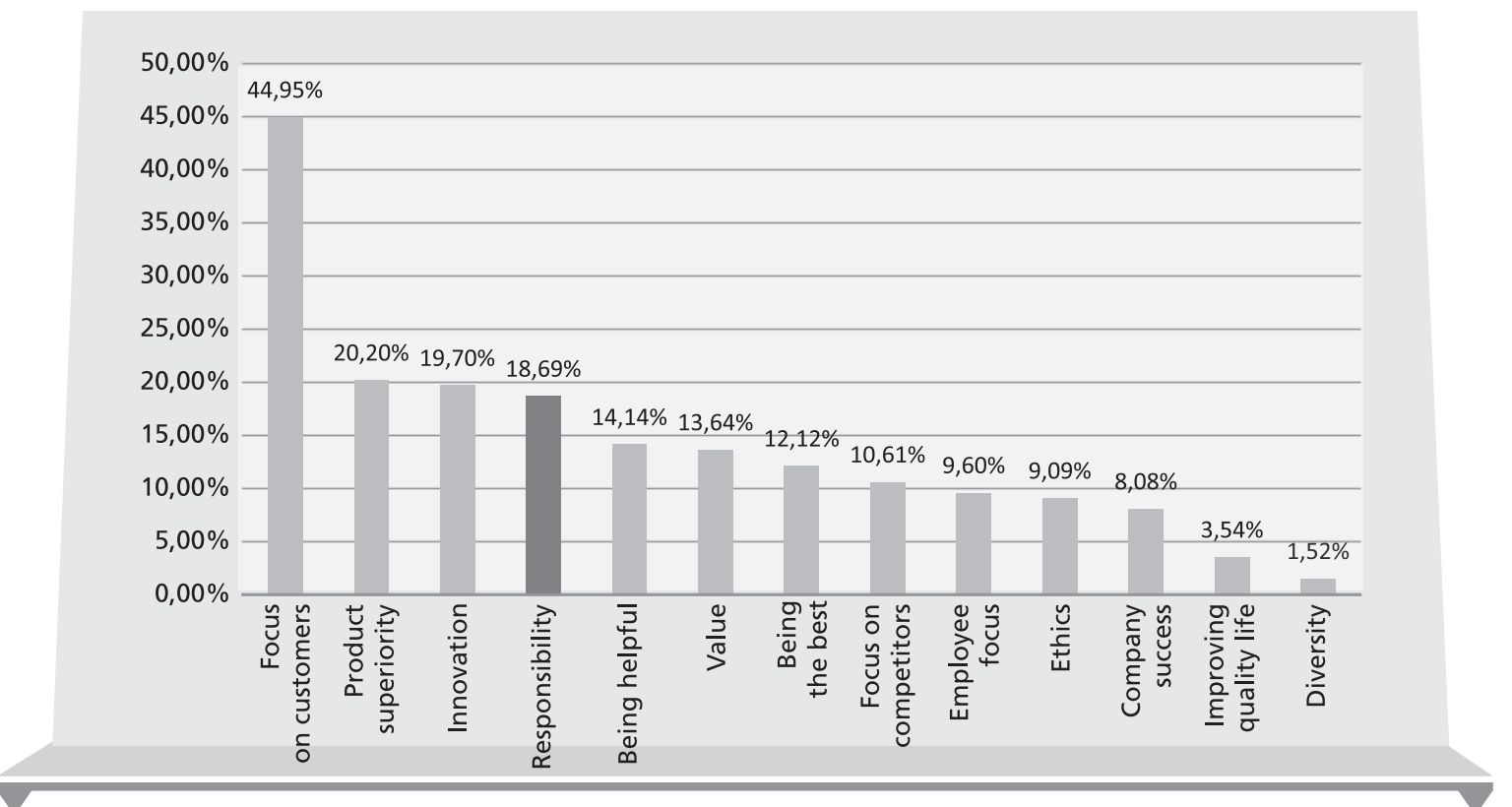

Figure 1. Value types in the missions of the analyzed enterprises, as presented on their corporate websites

Source: own study based on research results

The largest number from among the analyzed organizations $(44.95 \%)$ declared focus on customers in their missions. Less frequently, they included values such as: product superiority $(20.2 \%)$, innovation $(19.7 \%)$, or responsibility $(18.69 \%)$. Very few enterprises stressed the importance of improving the quality of life in society $(3.54 \%)$ or diversity of their activities $(1.52 \%)$.

In the analysis of the mission contents declared by the companies, the IRAMUTEQ software, along with a few others, was used as an auxiliary tool. Due to the fact the software does not come with a Polish dictionary, it was necessary to translate the mission contents into English. The text was prepared in accordance with the program requirements, and conjunctions, prepositions, most particles, etc. were removed ${ }^{6}$. For further analysis, those words whose number was greater than 9 were qualified. The number of individual words, their correlations and their intensity are shown in figure 2.

6 The program's automatic lemmatization feature enabled reducing „various inflectional forms found in the analyzed text to the basic form of the word, as well as identifying what part of speech they are" (Glińska-Neweś and Escher, 2018, p. 86).

The identity of the largest enterprises located in Poland and communication of corporate social activities on corporate 


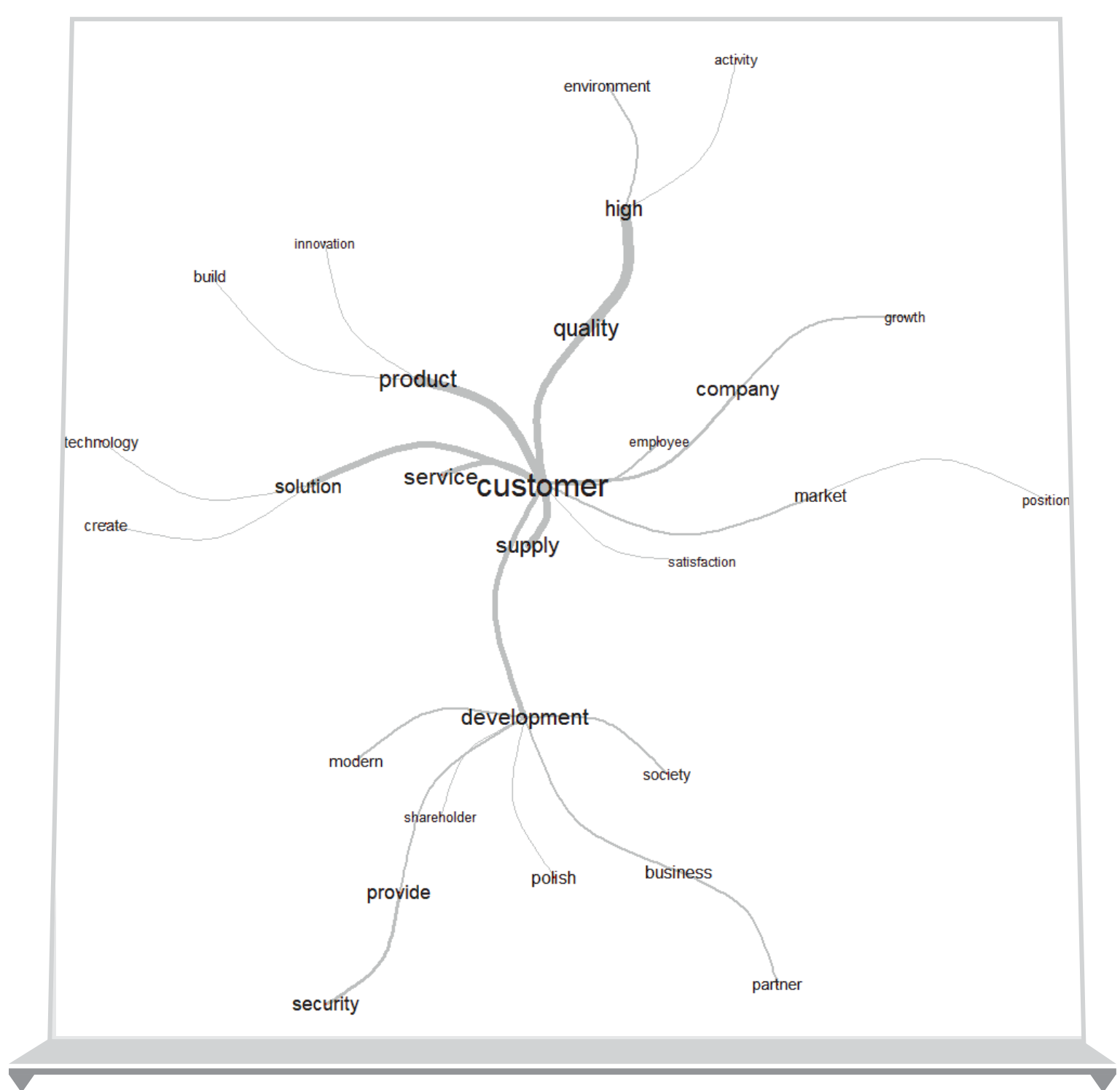

Figure 2. Correlations between the most common words used in the missions of the analyzed Polish enterprises

Source: own study based on research results

Having analyzed the information from figure 2, it was found that the entities' main focus was the customer (this term or its synonyms were identified in nearly half of the missions - 48.1\%), to whom high-quality products and services were provided. Every fourth mission (25.6\%) emphasized the importance of business development, while every fifth (21.1\%) - security, including a safe environment 
(14.3\%). The good (interest) of society was included in 16 missions (12\%), out of 133 identified as part of the study.

During the research, the values declared by the largest enterprises located in Poland were also analyzed. The taxonomy used for data coding was based on the proposal developed under the International Index of Corporate Values project (ECCO 2013), covering the following values: 1) professional values (e.g. quality, customer satisfaction, know-how, team spirit, excellence and service), 2) competitive values (e.g. ambition, anticipation, competitiveness, courage, enthusiasm), 3) behavioral values (e.g. adaptability, attention, attractiveness, authenticity, availability), 4) societal values (e.g. environmentalism, social responsibility, sustainability and health), 5) relational values (e.g. accessibility, communication, confidence, consideration), 6) fulfilling values (e.g. aesthetics, humanism, personal development), 7) moral values (e.g. ethics, integrity, loyalty), 8) social values (e.g. equality, equity, improving quality of life, integration).

Among the values posted on corporate websites, professional values were predominant (41.92\% of enterprises). Ethical values (37.88\%) and/or relational values $(36.36 \%)$ were declared in more than a third of the organizations, followed by those describing the organization's attitude towards the environment (30.81\%) (figure 3).

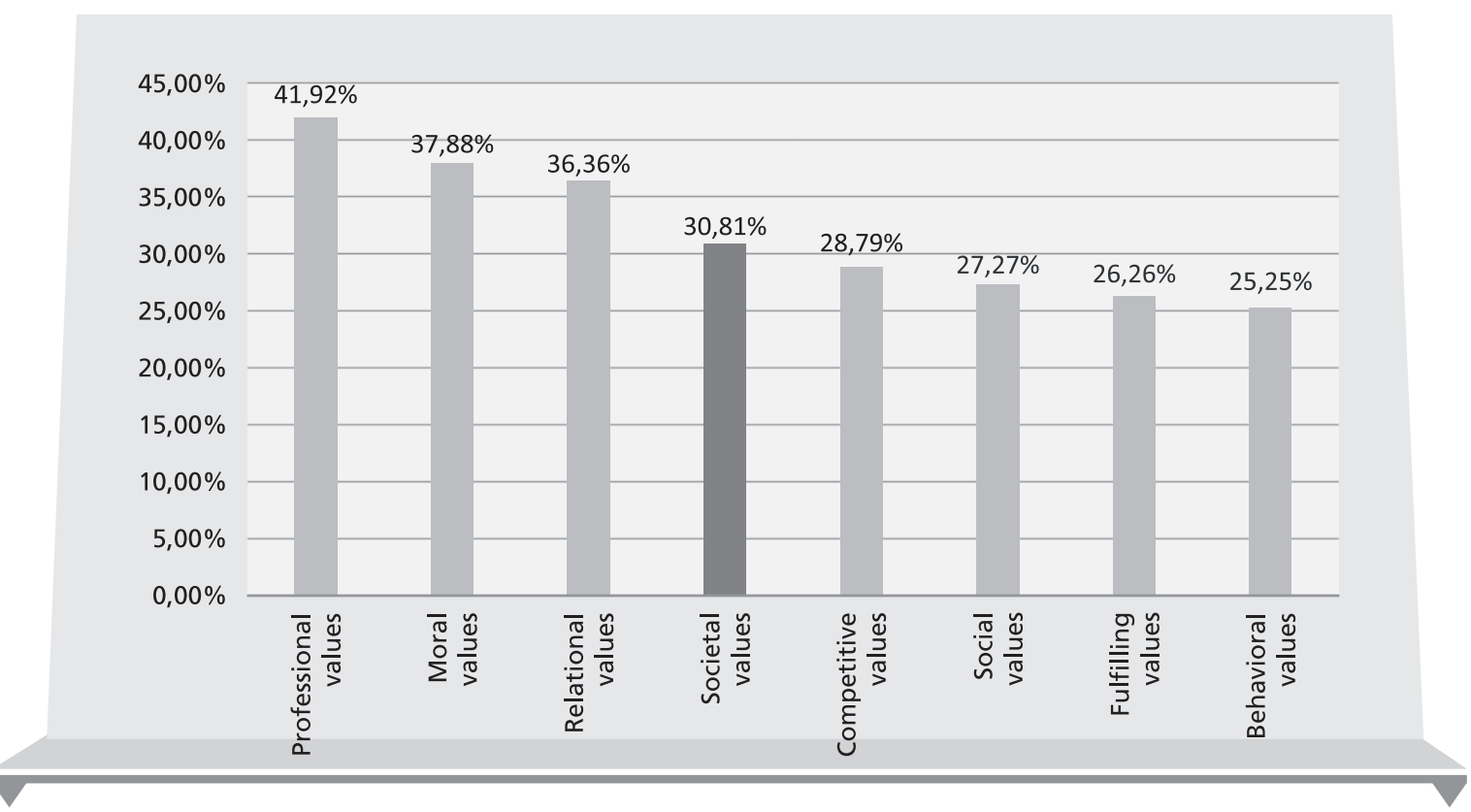

Figure 3. Values declared by the analyzed enterprises on their corporate websites

Source: own study based on research results 
To sum up, it can be said that two-thirds of the organizations $(62.12 \%)$ did not present a mission in which ",social responsibility" was emphasized, nor did they declare values ",shared with the environment". On the other hand, over a third $(37.88 \%)$ pointed via their corporate websites to the elements of organizational identity related to being a socially responsible enterprise (table 3).

Table 3. Prevalence of values related to social responsibility, as declared on corporate websites

\begin{tabular}{l|c|c}
\hline \multicolumn{1}{c|}{$\begin{array}{c}\text { Type of enterprise by declaration of CSR values } \\
\text { on corporate websites }\end{array}$} & N & [\%] \\
\hline $\begin{array}{l}\text { 1. Enterprises presenting a mission in which "social responsibility" was em- } \\
\text { phasized AND declaring values "shared with the environment" }\end{array}$ & 23 & 11,62 \\
\hline $\begin{array}{l}\text { 2. Enterprises presenting a mission in which "social responsibility" was em- } \\
\text { phasized, but NOT declaring values "shared with the environment" }\end{array}$ & 14 & 7,07 \\
\hline $\begin{array}{l}\text { 3. Enterprises NOT presenting a mission in which "social responsibility" was } \\
\text { emphasized (or NOT presenting any mission at all) BUT declaring values } \\
\text { "shared with the environment" }\end{array}$ & 38 & 19,19 \\
\hline $\begin{array}{l}\text { 4. Enterprises NOT presenting a mission in which "social responsibility" was } \\
\text { emphasized (or NOT presenting any mission at all) and NOT declaring values } \\
\text { "shared with the environment" }\end{array}$ & 123 & 62,12 \\
\hline \begin{tabular}{l} 
Total \\
\hline
\end{tabular}
\end{tabular}

Source: own study based on research results

Nearly every fifth organization (19.19\%) did not mention ",social responsibility" in their mission, but declared values ",shared with the environment". The opposite was true every fourteenth entity subject to analysis. Only every eighth (11.62\%) presented both mission and values in a consistent manner, which pointed to the importance of responsibility for the social environment.

The findings reveal that the minority of the analyzed organizations presented the components making up the identity of a socially responsible enterprise. Worse still, the vast majority of these failed to do it in a coherent way. This prompted the rejection of the hypotheses $\mathrm{H} 1$ and $\mathrm{H} 2$. 


\section{Corporate social activities of enterprises and their presentation on corporate websites vs. the mission and values related to social responsibility (results of hypothesis testing)}

The enterprises undertook social activities mainly by providing financial and material support to non-governmental organizations (52.53\%), public organizations (50.51\%, respectively) and individuals (24.75\%, respectively). The most frequently reported corporate social activity was support for activities benefiting local communities (55.05\%), sport (54.04\%), social assistance (51.52\%), and education $(49.49 \%)$. Some companies engaged their staff in employee volunteering (32.83\%). The initiatives were carried out either directly by the company, or indirectly - through a corporate foundation, the so-called BONGO (Business Organized Non-Governmental Organization'). The findings show that the analyzed enterprises used the following forms of agency in the pursuit of initiatives outlined above: a) own corporate foundation ${ }^{8}$, b) a foundation set up by the associated capital group, c) a foundation set up together with other companies, d) a selected external nonprofit organization, acting as a strategic partner in implementing social initiatives. Also identified were cases of initiatives from business owners who privately set up foundations dealing with social issues, regardless of the social engagement of their company.

Corporate social activity as a whole was also communicated either directly (on corporate websites) or indirectly - on the websites of corporate foundations. Based on the collected data, the hypotheses H3-H16 could be tested. For this purpose, a non-parametric test for independent random samples was used, namely the Mann-Whitney $U$ test (adjusted for continuity). This test can be used when the data is measurable but its distribution is abnormal, and when the variables are of the ordinal type (Blalock, 1975) [or when the variables are measured on a dichotomous scale (i.e. 0-1), as is with the nominal variable which is also an ordinal variable; http://www.naukowiec.org/wiedza/statystyka/testu-manna-whitneya_755.html; 02.07.2019 - access date]. This was the case in the research discussed in this paper.

The null hypothesis assumes in the case of the Mann-Whitney $U$ test that the types of distribution of the analyzed samples do not differ significantly, while the alternative hypothesis - that they differ significantly (for more, see Rabiej, 2012; Jóźwiak and Podgórski, 2009). If the p-value is below the materiality threshold, there are reasons to reject the null hypothesis (Moczko, 2014).

7 Among the analysed enterprises, every fourth $(24.75 \%)$ had a corporate foundation.

8 In one case it was an association.

The identity of the largest enterprises

located in Poland and communication

of corporate social activities on corporate 


\section{Table 4. Mann-Whitney U test results (with a continuity correction) (mission type "responsibility" and communication of corporate social activities on corporate websites)}

\begin{tabular}{|c|c|c|c|c|c|c|c|c|c|}
\hline \multirow{2}{*}{$\frac{\frac{0}{0}}{\stackrel{\frac{\pi}{3}}{\frac{\pi}{7}}}$} & \multicolumn{9}{|c|}{$\begin{array}{l}\text { Mann-Whitney U test results (with a continuity correction) (mission type "responsibility" } \\
\text { and communication of corporate social activities on corporate websites) by variable } \\
\text { Highlighted results considered significant at } p<, 05000\end{array}$} \\
\hline & $\begin{array}{l}\text { Rank sum } \\
\text { - Group } 1\end{array}$ & $\begin{array}{l}\text { Rank sum } \\
\text { - Group } 2\end{array}$ & $\mathrm{U}$ & Z & $\mathrm{P}$ & \begin{tabular}{c|}
$Z$ \\
adjusted
\end{tabular} & $\mathrm{P}$ & $\begin{array}{l}\text { N valid - } \\
\text { Group } 1\end{array}$ & $\begin{array}{l}\mathrm{N} \text { valid - } \\
\text { Group } 2\end{array}$ \\
\hline \multirow{16}{*}{ 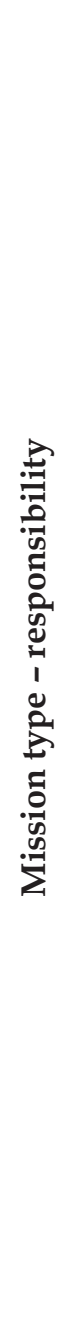 } & \multicolumn{9}{|c|}{ Communicating CSR awards } \\
\hline & 9009,000 & 10692,00 & 4587,000 & 0,630214 & 0,528555 & 0,933411 & 0,350608 & 88 & 110 \\
\hline & \multicolumn{9}{|c|}{ Communicating corporate social activities in the CSR reports } \\
\hline & 10269,00 & 9432,000 & 4076,000 & 2,025694 & 0,042797 & 3,000261 & 0,002698 & 95 & 103 \\
\hline & \multicolumn{9}{|c|}{ Communicating corporate social activities in the CSR section } \\
\hline & 10395,00 & 9306,000 & 4356,000 & 1,349360 & 0,177222 & 1,998541 & 0,045659 & 99 & 99 \\
\hline & \multicolumn{9}{|c|}{$\begin{array}{l}\text { Communicating the implementation of corporate social activities } \\
\text { in a material and/or financial form }\end{array}$} \\
\hline & 14103,00 & 5598,00 & 3582,000 & 1,784028 & 0,074420 & 2,642329 & 0,008234 & 135 & 63 \\
\hline & \multicolumn{9}{|c|}{$\begin{array}{l}\text { Communicating the implementation of corporate social activities } \\
\text { in the form of employee volunteering }\end{array}$} \\
\hline & 6930,000 & 12771,00 & 3993,000 & 0,953703 & 0,340235 & 1,412532 & 0,15794 & 66 & 132 \\
\hline & \multicolumn{9}{|c|}{ Communicating the implementation of corporate social activities for the benefit of NGOs } \\
\hline & 10800,00 & 8901,000 & 4436,000 & 1,12350 & 0,262140 & 1,660835 & 0,096748 & 104 & 94 \\
\hline & \multicolumn{9}{|c|}{$\begin{array}{l}\text { Communicating the implementation of corporate social activities } \\
\text { for the benefit of public organizations }\end{array}$} \\
\hline & 10674,00 & 9027,000 & 4176,000 & 1,794691 & 0,072704 & 2,658121 & 0,007858 & 100 & 98 \\
\hline & \multicolumn{9}{|c|}{$\begin{array}{l}\text { Communicating the implementation of corporate social activities } \\
\text { for the benefit of individuals }\end{array}$} \\
\hline & 5157,000 & 14544,00 & 3369,000 & 0,807568 & 0,419340 & 1,196092 & 0,231662 & 49 & 149 \\
\hline
\end{tabular}

Source: own study based on research

* U - Mann-Whitney test value used for small numbers <20

*Z - Mann-Whitney test value used when number of both groups greater than 20

${ }^{*} \mathrm{P}$ - significance level for the test for the $\mathrm{Z}$ test value 
* Z adjusted - test value adjusted for combined weights

${ }^{*} \mathrm{p}$ - significance level for $\mathrm{Z}$ adjusted

*N valid - numerical amount of groups

- highlighted results significant at $\mathrm{p}<, 05000$

The reasons for rejecting the research hypotheses $\mathrm{H}_{4}-\mathrm{H}_{6}$ and $\mathrm{H}_{9}$ were established, meaning there is no justification to consider that companies in whose missions social responsibility was highlighted do not communicate their corporate social activities on corporate websites by: publishing CSR reports, creating a separate CSR section, and sharing information on supporting public organizations in a material and financial form. However, no reasons were found for rejecting the research hypotheses $\mathrm{H}_{3}, \mathrm{H}_{7}$ and $\mathrm{H}_{8}$ (table 4), meaning there is no justification to recognize that companies in whose missions social responsibility was highlighted do not communicate their CSR awards, employee volunteering , or supporting non-governmental organizations and individuals.

\section{Table 5. Mann-Whitney U test results (with a continuity correction) (value type "attitude towards the environment" and communication of corporate social activities on corporate websites)}

\begin{tabular}{|c|c|c|c|c|c|c|c|c|c|}
\hline \multirow{2}{*}{ 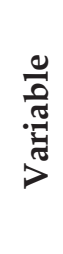 } & \multicolumn{9}{|c|}{$\begin{array}{l}\text { Mann-Whitney U test results (with a continuity correction) (value type "responsibility" and } \\
\text { communication of corporate social activities on corporate websites) by variable } \\
\text { Highlighted results considered significant at } p<, 05000\end{array}$} \\
\hline & $\begin{array}{l}\text { Rank sum } \\
- \text { Group } 1\end{array}$ & $\begin{array}{l}\text { Rank sum } \\
- \text { Group } 2\end{array}$ & $\mathrm{U}$ & Z & $\mathrm{P}$ & \begin{tabular}{c|c}
$\mathrm{Z}$ \\
adjusted
\end{tabular} & $\mathrm{P}$ & $\begin{array}{l}\text { N valid }- \\
\text { Group } 1\end{array}$ & $\begin{array}{l}\mathrm{N} \text { valid - } \\
\text { Group } 2\end{array}$ \\
\hline \multirow{8}{*}{ 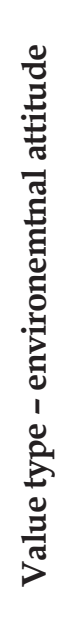 } & \multicolumn{9}{|c|}{ Communicating CSR awards } \\
\hline & 10131,00 & 9570,000 & 3465,000 & 3,430608 & 0,000602 & 4,289878 & 0,000018 & 88 & 110 \\
\hline & \multicolumn{9}{|c|}{ Communicating corporate social activities in the CSR reports } \\
\hline & 11208,00 & 8493,000 & 3137,000 & 4,356731 & 0,000013 & 5,447969 & 0,000000 & 95 & 103 \\
\hline & \multicolumn{9}{|c|}{ Communicating corporate social activities in the CSR section } \\
\hline & 11385,00 & 8316,000 & 3366,000 & 3,804996 & 0,000142 & 4,758040 & 0,000002 & 99 & 99 \\
\hline & \multicolumn{9}{|c|}{$\begin{array}{l}\text { Communicating the implementation of corporate social activities } \\
\text { in a material and/or financial form }\end{array}$} \\
\hline & 14562,00 & 5139,000 & 3123,000 & 3,006221 & 0,002645 & 3,759194 & 0,000170 & 135 & 63 \\
\hline
\end{tabular}

The identity of the largest enterprises located in Poland and communication of corporate social activities on corporate 


\begin{tabular}{l|r|r|r|r|r|r|r|r|r}
\hline \multicolumn{7}{|c}{ Communicating the implementation of corporate social activities } \\
in the form of employee volunteering \\
\hline
\end{tabular}

The reasons for rejecting the research hypotheses $\mathrm{H}_{10}-\mathrm{H}_{16}$ were also found, meaning there is no justification to consider that companies declaring societal values do not communicate their corporate social activities on corporate websites (table 6).

Table 6. Results of testing hypotheses $\mathrm{H}_{3}-\mathrm{H}_{16}$

\begin{tabular}{c|l|c|l}
\hline $\begin{array}{c}\text { Research } \\
\text { hypotheses }\end{array}$ & \multicolumn{1}{|c|}{ Testing result } & $\begin{array}{c}\text { Research } \\
\text { hypotheses }\end{array}$ & \multicolumn{1}{c}{ Testing result } \\
\hline $\mathrm{H}_{3}$ & No reasons for rejection found & $\mathrm{H}_{10}$ & Reasons for rejection found \\
\hline $\mathrm{H}_{4}$ & Reasons for rejection found & $\mathrm{H}_{11}$ & Reasons for rejection found \\
\hline $\mathrm{H}_{5}$ & Reasons for rejection found & $\mathrm{H}_{12}$ & Reasons for rejection found \\
\hline
\end{tabular}




\begin{tabular}{l|l|l|l}
$\mathrm{H}_{6}:$ & Reasons for rejection found & $\mathrm{H}_{13}$ & Reasons for rejection found \\
\hline $\mathrm{H}_{7}$ & No reasons for rejection found & $\mathrm{H}_{14}$ & Reasons for rejection found \\
\hline $\mathrm{H}_{8}$ & No reasons for rejection found & $\mathrm{H}_{15}$ & Reasons for rejection found \\
\hline $\mathrm{H}_{9}$ & Reasons for rejection found & $\mathrm{H}_{16}$ & Reasons for rejection found \\
\hline
\end{tabular}

Source: own study based on research

Due to the fact that reasons were found for rejecting the majority of the hypotheses - further analysis was performed, the results of which are shown in table 7. It concerned types of enterprises in relation to declaring social responsibility in their missions and/or values as well as the content of their messages connected with corporate social activities.

Table 7. Type of enterprise by declaring social responsibility in missions and/or values and the content of messages connected with corporate social activities

\begin{tabular}{|c|c|c|c|c|c|}
\hline $\begin{array}{l}\text { Type of enterpris- } \\
\text { es by declaring } \\
\text { social responsibil- } \\
\text { ity in missions } \\
\text { and/or values }\end{array}$ & $\begin{array}{c}\text { Number of } \\
\text { enterpri- } \\
\text { ses }\end{array}$ & $\begin{array}{c}\text { Content of messages connected } \\
\text { with corporate social activities on } \\
\text { corporate websites }\end{array}$ & $\begin{array}{l}\text { Number of } \\
\text { enterprises } \\
\text { presenting } \\
\text { particular } \\
\text { contents of } \\
\text { messages }\end{array}$ & $\begin{array}{c}\text { Share } \\
{[\%]}\end{array}$ & $\begin{array}{c}\text { Coeffi- } \\
\text { cient of } \\
\text { variation } \\
\mathbf{V} \\
{[\%]}\end{array}$ \\
\hline \multirow{8}{*}{$\begin{array}{l}\text { 1. presenting } \\
\text { a mission in } \\
\text { which "social } \\
\text { responsibility" } \\
\text { was emphasized } \\
\text { AND declaring } \\
\text { values "shared } \\
\text { with the environ- } \\
\text { ment" }\end{array}$} & \multirow{8}{*}{23} & Receiving CSR awards & 14 & 60,87 & \multirow{8}{*}{28,02} \\
\hline & & CSR section & 16 & 69,57 & \\
\hline & & CSR reports & 9 & 39,13 & \\
\hline & & Employee volunteering & 10 & 43,48 & \\
\hline & & $\begin{array}{l}\text { Offering financial, material sup- } \\
\text { port }\end{array}$ & 21 & 91,30 & \\
\hline & & Supporting NGOs & 17 & 73,91 & \\
\hline & & Supportitng public organizations & 17 & 73,91 & \\
\hline & & Supporting individuals & 10 & 43,48 & \\
\hline
\end{tabular}

The identity of the largest enterprises located in Poland and communication of corporate social activities on corporate 
2. presenting a mission in which ,social responsibility" was emphasized, but NOT declaring values "shared with the environment"

\begin{tabular}{|c|c|c|c|c|}
\hline \multirow{8}{*}{14} & Receiving CSR awards & 5 & 35,17 & \multirow{8}{*}{39,17} \\
\hline & CSR section & 8 & 57,14 & \\
\hline & CSR reports & 5 & 35,71 & \\
\hline & Employee volunteering & 6 & 42,86 & \\
\hline & $\begin{array}{l}\text { Offering financial, material sup- } \\
\text { port }\end{array}$ & 11 & 78,57 & \\
\hline & Supporting NGOs & 7 & 50,00 & \\
\hline & Supportitng public organizations & 9 & 64,29 & \\
\hline & Supporting individuals & 2 & 14,29 & \\
\hline
\end{tabular}

3. NOT presenting a mission in which "social responsibility" was emphasized (or NOT presenting any mission at all) BUT declaring values "shared with the environment"

\begin{tabular}{|c|c|c|c|c|}
\hline \multirow{8}{*}{38} & Receiving CSR awards & 27 & 71,05 & \multirow{8}{*}{20,71} \\
\hline & CSR section & 29 & 76,32 & \\
\hline & CSR reports & 24 & 63,16 & \\
\hline & Employee volunteering & 22 & 57,89 & \\
\hline & Offering financial, material support & 32 & 84,21 & \\
\hline & Supporting NGOs & 29 & 76,32 & \\
\hline & Supportitng public organizations & 29 & 76,32 & \\
\hline & Supporting individuals & 14 & 36,84 & \\
\hline
\end{tabular}

4. NOT presenting a mission in which "social responsibility" was emphasized (or NOT presenting any mission at all) and NOT declaring values "shared with the environment"

\begin{tabular}{|c|c|c|c|}
\hline Receiving CSR awards & 42 & 34,14 & \multirow{8}{*}{39,62} \\
\hline CSR section & 38 & 30,89 & \\
\hline CSR reports & 20 & 16,26 & \\
\hline Employee volunteering & 27 & 21,95 & \\
\hline Offering financial, material support & 71 & 57,72 & \\
\hline Supporting NGOs & 51 & 41,46 & \\
\hline Supportitng public organizations & 45 & 36,59 & \\
\hline Supporting individuals & 23 & 18,70 & \\
\hline
\end{tabular}




\begin{tabular}{|c|c|c|c|c|c|}
\hline \multirow{8}{*}{$\begin{array}{l}\text { Enterprises - } \\
\text { Total }\end{array}$} & \multirow{8}{*}{198} & Receiving CSR awards & 88 & 44,44 & \multirow{8}{*}{30,52} \\
\hline & & CSR section & 91 & 45,96 & \\
\hline & & CSR reports & 58 & 29,29 & \\
\hline & & Employee volunteering & 65 & 32,83 & \\
\hline & & $\begin{array}{l}\text { Offering financial, material sup- } \\
\text { port }\end{array}$ & 135 & 68,19 & \\
\hline & & Supporting NGOs & 104 & 52,53 & \\
\hline & & Supportitng public organizations & 100 & 50,51 & \\
\hline & & Supporting individuals & 49 & 24,75 & \\
\hline
\end{tabular}

Source: own study based on research

The results of the analysis of the data in table 7 confirmed the results of testing the $\mathrm{H} 3-\mathrm{H}_{16}$ hypotheses. More categories of messages were presented by those enterprises that declared societal values. Data dispersion for each of the four types of enterprises analyzed was moderate ${ }^{9}$. The lowest value of the coefficient of variation $(20.71 \%)$ was recorded in the third type of organizations, i.e. entities not presenting a mission in which "social responsibility" is emphasized (or not presenting any mission at all), butdeclaring values "shared with theenvironment". We should add that these companies most often published CSR messages on their corporate websites (this concerned six out of the eight categories of messages shown in table 7). On the other hand, companies representing the fourth type [not presenting a mission in which "social responsibility" is emphasized or not making any mission available online) and not declaring values "shared with the environment" published this information the least frequently (lowest values obtained for seven out of the eight categories of messages) .

9 Interpreting the coefficient of variation, it was assumed that: 0-20\% denotes a slight variation in the value of the variable, the group is relatively homogeneous, the arithmetic mean is an adequate measure characterizing the group; $20-40 \%$ - a moderate variation in the value of the variable, the arithmetic mean is an acceptable measure for the variable; $40-60 \%$ - a strong variation in the value of the variable, the dispersion of the variable is significant, the arithmetic mean has little cognitive value; $60 \%$ or more - a very strong variation in the value of the variable, the group is heterogeneous, the arithmetic mean has no cognitive value (Zając, 1988, p. 209).

The identity of the largest enterprises located in Poland and communication of corporate social activities on corporate 


\section{Conclusion}

Mission and values are important elements of organizational identity. They can be a source of expression of business philosophy (Collins and Porras, 1991), a tool for articulating beliefs about the functioning of an enterprise. The research shows that two-thirds of the analyzed companies posted missions on their corporate websites. In most cases they declared focus on costumers, and less often - product superiority, innovation, or responsibility.

Less than half of the companies presented organizational values through their websites. Those which prevailed are: professional, ethical, relational, and describing attitudes towards the environment. The analysis shows that every second analyzed company presented missions and values that referred to issues related to social responsibility.

In managing identity, coherence between the mission and values and the actual efforts and their communication is very important, which is why exploring these correlations was a priority in this study. Research findings based on the obtained data (including the results of hypothesis testing) showed that enterprises that included references to responsibility towards the environment in their mission communicated only a part of their activities, which may suggest that they did not really take action in that area. It was different in the case of enterprises which pointed to the importance of societal values among the declared values. Such organizations, according to our analysis, more often pursued CSR activities and communicated them. Therefore, a conclusion can be made that a better predictor of the effects of identity management in the area of CSR was the declaration of values related to social responsibility.

Finally, it should be noted that no real actions were studied, but only statements posted on corporate websites. The lack of such information does not necessarily mean an enterprise does not engage in corporate social activities, but simply that it does not communicate such efforts. It will therefore be worth updating the research with case studies, interviews and surveys in the future. It should also be noted that the research concerned the largest enterprises located in Poland, meaning it was carried out in a specific cultural context. Hence, comparative research might also be considered to fill this gap. 


\section{Summary}

The identity of the largest enterprises located in Poland and communication of corporate social activities on corporate websites

Today's enterprises are becoming more and more socially active. In some respects, they are starting to resemble third-sector organizations. In the context of progressive isomorphism, the issue of organizational identity deserves attention. Identity is based, among others, on organizational mission and values, whose management requires the shaping of coherent links between these components, as well as actual efforts and their communication. Modern enterprises are markedly fond of using electronic media, including corporate websites, to communicate with the audience. The purpose of the article is to determine the prevalence of different types of missions and values among the largest enterprises located in Poland, especially those related to CSR, as well as to identify the relationship between their declared CSR missions and values and the presentation of selected corporate social activities on their corporate websites. It was found that two-thirds of the analyzed companies posted missions on their corporate websites. In most cases they declared focus on costumers, and less often - product superiority, innovation, or responsibility. Less than half of the companies presented organizational values through their websites. Those which prevailed are: professional, ethical, relational, and describing attitudes towards the environment. The analysis shows that every second analyzed company presented missions and values that referred to issues related to social responsibility. Enterprises that included references to responsibility towards the environment in their mission communicated only some of the corporate social activities. It was different in the case of enterprises which pointed to the importance of societal values among the declared values. Such organizations more often pursued CSR activities and communicated them. Therefore, it can be conclude that a better predictor of the effects of identity management in the area of CSR was the declaration of values related to social responsibility.

Keywords: organizational identity, CSR, mission, values, corporate websites, communication.

The identity of the largest enterprises

located in Poland and communication

of corporate social activities on corporate 


\section{Streszczenie}

Tożsamość największych polskich przedsiębiorstw a komunikowanie działań społecznych na korporacyjnych stronach internetowych

Współcześnie przedsiębiorstwa coraz bardziej aktywizują się w obszarze społecznym. Pod pewnymi względami zaczynają przypominać tzw. organizacje trzeciego sektora. W kontekście postępującego izomorfizmu na uwage zasługuje zagadnienie tożsamości organizacji. Podstawę tożsamości stanowią, m.in. misja i wartości organizacyjne, a zarządzanie nią wymaga kształtowania spójnych powiązań pomiędzy tymi elementami a realnymi działaniami i ich komunikowaniem. Nowoczesne przedsiębiorstwa $\mathrm{W}$ istotnym stopniu wykorzystują do komunikowania się z publicznością media elektroniczne, w tym korporacyjne strony internetowe.

Celem artykułu jest ustalenie powszechności występowania wśród największych polskich przedsiębiorstw różnych typów misji i wartości, zwłaszcza tych, które odnoszą się do CSR, a także zidentyfikowanie relacji między deklarowanymi przez te przedsiębiorstwa misjami i wartościami związanymi z CSR a prezentowaniem przez nie wybranych działań społecznych poprzez korporacyjne strony internetowe. Ustalono, że dwie trzecie badanych firm zamieszczało na swoich korporacyjnych stronach internetowych misje. Najczęściej deklarowały w nich koncentrację na kliencie, rzadziej - wyższość produktu, innowacyjność czy odpowiedzialność. Mniej niż połowa firm przedstawiała za pomocą stron internetowych wartości organizacyjne. Przeważały - zawodowe, etyczne, związane $z$ relacjami i opisujacce postawę wobec otoczenia. Przedsiębiorstwa, które w misji umieściły odniesienia do odpowiedzialności wobec otoczenia komunikowały tylko niektóre działania społeczne. Inaczej było w przypadku przedsiębiorstw, które wśród deklarowanych wartości wskazywały na znaczenie wartości społecznych. Takie organizacje częściej podejmowały działania CSR i komunikowały o nich. Można wysnuć wniosek, że lepszym predykatorem efektów zarządzania tożsamością organizacji w obszarze CSR było deklarowanie wartości odnoszących się do społecznej odpowiedzialności. 


\section{Słowa}

kluczowe: tożsamość organizacji, CSR, misja, wartości, korporacyjne strony internetowe, komunikacja.

JEL

Classification: D20, D64, L10, L20, L31, M14, M30

\section{References}

1. Albert, S., Whetten, D.A. (1985). Organizational Identity. In: Staw, B.M., Cummings, L.L., (eds.). Research in Organizational Behavior (pp. 263-295). Greenwich: JAI Press.

2. Babbie, E. (2008). Podstawy badań społecznych. Warszawa: PWN.

3. Blalock, H. (1975). Statystyka dla socjologów, Warszawa: PWN.

4. Carroll, A.B. (1991). The pyramid of corporate social responsibility: toward the moral management of organizational stakeholders. Business Horizons, No. 34, pp. 39-48.

5. Carter, D.E. (1982). Designing corporate identity programs for small corporations. New York: Art Direction Book Company.

6. Carvalho, A., Melo, S., Ferreira, A.P. (2016). Training in Portuguese nonprofit organizations: the quest towards professionalization. International Journal of Training and Development, Vol. 20, No.1, pp. 78-91. DOI: 10.1111/ ijtd.12070.

7. Collins, J.C., Porras, J.I. (1991). Organizational vision and visionary organizations. California Management Review, Vol. 37, Iss. 1, pp. 30-52. DOI: $10.2307 / 41166682$.

8. Cooney, K. (2006). The institutional and technical structuring of nonprofit ventures: case study of a U.S. hybrid organization caught two fields. Voluntas, Vol. 17, No. 2, pp. 143-161. DOI: 10.1007/s11266-006-9010-8.

9. Cumming, G.D. (2008). French NGOs in the global era: professionalization "Without Borders"? Voluntas, Vol. 19, No. 4, pp. 372-394. DOI: 10.1007/ s11266-008-9060-5.

10. Cunningham, S., Cornwell, T.B., Coote, L.V. (2009). Expressing Identity and Shaping Image: The Relationship Between Corporate Mission and Corporate Sponsorship. Journal of Sport Management, Vol. 23, Iss. 1, pp. 6586. DOI: $10.1123 /$ jsm.23.1.65.

11. Dees, J. G. (1998). Enterprising Nonprofits. Harvard Business Review, Vol. 76, Iss. 1. pp. 54-61.

12. Dowling, G. R., Otubanjo, T. (2011). Corporate and organizational identity: two sides of the same coin. Academy of Marketing Science, Vol. 1(3), pp. 171182. DOI: $10.1007 / \mathrm{s} 13162-011-0022-1$.

13. Dutton, J. E., Dukerich, J. M., Harquail, C. V. (1994). Organizational images and member identification. Administrative Science Quarterly, Vol. 39, No. 2, pp. 239-263. DOI: $10.2307 / 2393235$.

The identity of the largest enterprises

located in Poland and communication

of corporate social activities on corporate 
14. ECCO (2013). International Index of Corporate Values. https://www. zoebelicom.ch/fileadmin/user_upload/Aktuell/Q_A_Corporate_ Values_2013.pdf (02.04.2019 - access date).

15. Eikenberry, A.M., Kluver, J.D. (2004). The marketization of the nonprofit sector: civil society at risk? Public Administration Review, Vol. 64, No. 2, pp.132-140. DOI: 10.1111/j.1540-6210.2004.00355.x.

16. Gioia, D.A., Hamilton, A.L., Patvardhan, S.D. (2014). Image is everything. Reflections on the dominance of image in modern organizational life. Research in Organizational Behavior, Vol. 34, pp. 129-154. DOI: 10.1016/j. riob.2014.01.001.

17. Glińska-Neweś, A., Escher, I. (2018). Analiza treści w badaniach zjawisk społecznych w organizacji : zastosowanie programu IRAMUTEQ. Studia Oeconomica Posnaniensia, Vol. 6, No. 3, pp. 73-94. DOI: 10.18559/ SOEP.2018.3.4.

18. Gray, E. R., Balmer, J. M. (1998). Managing corporate image and corporate reputation. Long Range Planning, Vol. 31, No. 5, pp. 695-702. DOI: 10.1016/ S0024-6301(98)00074-0.

19. Hatch, M. J. (2002). Teoria organizacji. Warszawa: PWN

20. http://www.naukowiec.org/wiedza/statystyka/test-u-mannawhitneya_755.html (02.07.2019 - access date).

21. https:// rankingi.wprost.pl/200-najwiekszych-firm/2018 (24.02.2019 access date).

22. Hwang, H., Powell, W.W. (2009). The rationalization of charity: the influences of professionalism in the nonprofit sector. Administrative Science Quarterly, No. 54, No. 2, pp. 268-298. DOI: 10.2189/asqu.2009.54.2.268.

23. Insch, G.S., Moore, J.E., Murphy, L.D. (1997). Content analysis in leadership research: Examples, procedures and suggestions for future use. The Leadership Quarterly, No. 8(1), pp. 1-25. DOI: 10.1016/S10489843(97)90028-X.

24. Jäger, U., Schröer, A. (2014). Integrated organizational identity: a definition of hybrid organizations and a research agenda. Voluntas, Vol. 25, pp. 12811306. DOI: 10.1007/s11266-013-9386-1.

25. Jóźwiak, J., Podgórski, J. (2009). Statystyka od podstaw. Warszawa: PWE.

26. Knutsen, W. (2016). The non-profit sector is dead, long live non-profit sector. Voluntas, Vol. 27, No. 4, pp. 1562-1584. DOI: 10.1007/s11266-0169696-1.

27. Kończak, J. (2017). Rola komunikacji korporacyjnej w Polsce. Studia Medioznawcze, No. 1, pp. 45-63.

28. Konecki, K. (2002). Tożsamość organizacyjna. In: Konecki K., Tobera, P. (eds). Szkice z socjologii zarządzania (pp. 82-102). Łódź: Wydawnictwo Uniwersytetu Łódzkiego.

29. Kreutzer, K., Jäger, U. (2011). Volunteering versus managerialism: conflict over organizational identity in voluntary associations. Nonprofit 
and Voluntary Sector Quarterly, Vol. 40, No. 4, pp. 634-661. DOI: $10.1177 / 0899764010369386$.

30. Lloyd, S., Woodside, A. (2015). Advancing paradox resolution theory for interpreting non-profit, commercial, entrepreneurial strategies. Journal of Strategic Marketing, Vol. 23, No. 1, pp. 1-18. DOI: 10.1080/0965254X.2014.914064.

31. Martinez, P., Perez, A., Rodriguez del Bosque, I. (2013). Exploring the role of CSR in the organizational identity of hospitality companies: a case from the Spanish tourism industry. Journal of Business Ethics, Vol. 124, pp. 47-66. DOI: 10.1007/s10551-013-1857-1.

32. Melewar, T., Karaosmanoglu, E. (2006). Seven dimensions of corporate identity. European Journal of Marketing, Vol. 40, No.7/8, pp. 846-869. DOI: 10.1108/03090560610670025.

33. Melnik, E., Petrella, F., Richez-Battesti, N. (2013). Does the professionalism of management practices in nonprofits and for-profits affect job satisfaction? The International Journal of Human Resource Management, Vol. 24, No. 6, pp. 1300-1321. DOI: 10.1080/09585192.2012.712543.

34. Moczko, J.A. (2014). Czy zawsze prawidłowo interpretujemy wyniki statystycznych testów nieparametrycznych. Prace Pogladowe, http:// www.wple.net/plek/numery_2014/numer-11-2014/654-658.pdf (01.07.2019 - access date).

35. Olins, W. (1978). The corporate personality: an inquiry into the nature of corporate identity. London: Thames and Hudson.

36. Olins, W. (1995). The new guide to identity. London: Gower.

37. Pilditch J. (1970), Communication by design: a study in corporate identity. London: McGraw-Hill.

38. PN-ISO 26000:2012, Wytyczne dotyczace spotecznej odpowiedzialności, PKN.

39. Pope, S., Bromley, P., Lim, A., Meyer, J.W. (2018). The pyramid of nonprofit responsibilities: The institutionalization of organizational actorhood across sectors. Voluntas, Vol. 29, No. 6, pp. 1300-1314. DOI: $10.1007 / \mathrm{s} 11266-018-0038-3$.

40. Rabiej, M. (2012). Statystyka z programem STATISTICA. Gliwice: Helion.

41. Sanzo-Perez, M.J., Rey-Garcia, M., Alvarez-Gonzalez, L.I. (2017). The drivers of voluntary transparency in nonprofits: professionalization and partnerships with firms as determinants. Voluntas, Vol. 28, No. 4, pp. 15951621. DOI: $10.1007 /$ s11266-017-9882-9.

42. Seitanidi, M.M., Crane, A. (2009). Implementing CSR through partnerships understanding the selection, design and institutionalization of nonprofitbusiness partnerships. Journal of Business Ethics, No. 85, pp. 423-429. DOI: $10.1007 /$ s10551-008-9743-y.

43. Silverman, D. (2009). Interpretacja danych jakościowych. Warszawa: PWN.

The identity of the largest enterprises

located in Poland and communication

of corporate social activities on corporate 
44. Simões, C., Dibb, S., Fisk, R.P. (2005). Managing corporate identity: an internal perspective. Journal of the Academy of Marketing Science, Vol. 33, No. 2, pp. 153-168. DOI: 10.1177/0092070304268920.

45. Weisbrod, B.A. (ed.) (1998). To profit or not to profit. The commercial transformation of the nonprofit sector. Cambridge: Cambridge University Press.

46. Whetten, D.A., Mackey A. (2002). A social actor conception of organizational identity and its implications for the study of organizational reputation. Business and Society, Vol. 41, pp. 393-414. DOI: 10.1177/0007650302238775.

47. Young, D. (2001a). Social enterprise in the United States: alternate identities and forms. Prepared for the EMES Conference, The Social Enterprise: A Comparative Perspective, Trento, Italy, December 13-15, www.comunity-wealth.org (01.08. 2006 - access date).

48. Young, D. (2001b). Organizational identity in nonprofit organizations: strategic and structural implications. Nonprofit Management and Leadership, Vol. 12, Iss. 2, pp. 139-157. DOI: 10.1002/nml.12202.

49. Zając K. (1988). Zarys metod statystycznych. Warszawa: Państwowe Wydawnictwo Ekonomiczne. 